\title{
Multiple Intelligences in Communication Classroom
}

\author{
Samra Javed \\ Dr. Fouzia Naeem Khan
}

\begin{abstract}
The theory of multiple intelligences was put forward by Dr. Howard Gardner, who is a professor of education at Harvard, in 1983. The theory shifts our attention from the stereotyped conception of intelligence, based on I.Q. testing, to nine different intelligences so as to explain a diverse range of human potential. This paper will identify the type of intelligence each of the target group (students of Communication) has, identify the teaching methods used to teach the target group and find out whether the teaching methods cater to the type of intelligence the target group has. This study shows that target group is diverse in terms of multiple intelligences but the ranking of target group intelligence does not correlate with that of class activities used to teach these students. The linguistic intelligence, predominantly catered to in the class activities, was not the dominant intelligence in this group and the dominant intelligence.
\end{abstract}

Key Words: Multiple Intelligences, Diversity, Dominant Intelligence, Teaching Methodology

\section{Introduction}

The theory of Multiple Intelligences represents a new point of reference towards intelligences (Goodnough, 2000). Howard Gardner, a professor of education at Harvard University, in his most renowned book, "Frames of Mind", proposed this theory in 1983. Since that time, this theory has been applied to teaching and learning.

According to Armstrong, although the theory of multiple intelligences has been the focus the attention of many educators in the U.S, still out there are many schools that teach in the same outdated way, such as, boring lectures, worksheets and textbooks. The challenge present to the institution in Pakistan is pretty huge as except for the elite schools in Pakistan, the majority of the teaching methodologies does not cater to multiple intelligences and include the traditional teaching methods.

Gardner places his theory as opposed to the traditional view of the intellect. He presented an altogether novel conception of the human intelligence.

This new concept is in contract with the conventionally established concept which states that the human intelligence is a linear concept which is measured by IQ tests. (Abdallah, 2008) MI Theory also suggests that every one has the capability to comprehend and learn about the world around him. The pioneer of the modern day kindergarten, Friedrich Froebel, developed a curriculum based on practical experiences. (Dorathy, 1999)

Samra Javed is a student of MS Social Sciences at SZABIST.

Dr. Fauzia Naeem Khan is Dean of Social and Media Sciences at SZABIST, Karachi.

Journal of Independent Studies and Research - MSSE

Volume $8 \quad$ Number 1

January 2010 189 
Educationists like Maria Montessori and John Dewy developed innovative systems of teaching based upon multiple-intelligences in the 20th century. (Abdallah, 2008) Instruction based on Multiple Intelligences in teaching English can be effective in many ways. Instruction of the English language on MI Theory means that the teacher should use an assortment of teaching strategies to address the intelligences dominated in the students. The model of instruction that employs the MI philosophy teaches English language in a natural environment. (Abdallah, 2008)

\section{Literature Review}

Kristi A. Schaller and Marybeth G. Callison in the paper titled "Multiple Intelligence and Student Learning: Reframing our Teaching Methods in the Basic Public Speaking Course" elaborates that speaking courses in English language are perfect forum to utilize the strategies to employ multiple intelligences, for example, students can be given choice to select the topic related to their personal intelligence. The paper further recommends a list of assignments and class activities that address the different types of intelligences. The paper suggests that the basic public speaking course is an ideal forum to incorporate MI theory and that instructors should use a variety of teaching methods to stimulate students' multiple intelligences. The paper describes MI theory and suggests assignments and activities that public speaking instructors might consider.

Anna Marie Safi in the paper titled, "Ditch the Dictionary" applies the theory of Multiple Intelligences to vocabulary development and reading instruction in the English as a Second Language Classroom. The paper supports the theory of Multiple Intelligences and maintains that in most of the learners, one kind of intelligence dominates though they possess some degree of all kinds of intelligences. It also states that the fact that the differences are not tolerated in a traditional classroom makes learner internalize that the real intelligent people are only 'word; or 'logic' smart. Ditch the Dictionary was a teacher training workshop presented at the International Institute of Rhode Island in 1994. The workshop evolved a discussion of possibilities for making use of the theory of Multiple Intelligences in a vocabulary classroom. The paper further suggests that a variety of possible activities catering to intelligences should be modeled and practiced; experiments with nontraditional "smarts" and suggests that the students should be allowed time to observe the class in action so as to learn about their own personal learning style.

Peter Smagorinsky in "Multiple Intelligences in the English Class: An Overview" describes how he increasingly encouraged students to represent their understanding of literature through unconventional types of compositions and understanding. His reading of Gardner suggested to him that students who would draw or dance an interpretation of literature were engaging in many of the same developmental processes they would experience when writing, and perhaps engage in other important processes as well that were not available through writing. The study revealed that in composing their texts the students engaged in a variety of processes that teachers value in writing, such as, drawing on a wealth of personal experiences to inform their reading of the story and to compose their texts; empathizing with the characters by relating parallel experiences; 
imbuing their texts with personal meaning; and representing their understanding symbolically.

Wendy F. Simeone in the paper, "Accommodating Multiple Intelligences in the English Classroom" offers activities for the kinesthetic learner, stating that most of the English teachers plan lessons which accommodate only visual and auditory learners. He describes using kinesthetic approaches, such as, video camera and films. In an activity, students were expected to demonstrate awareness of theme of a book by composing with a camera instead of pen. Students that were interested in music particularly enjoyed the project. One of his favorite kinesthetic language arts activities was a game he called "Chalkboard Pictionary." The activity visualized in concrete terms the symbolic and metaphorical power of proverbs. The author claimed that he was always struck by the talent of some of his students who often were the least talented with paper, pen, and word but were outstanding with picture conceptualizations. This realization had led him to offer more picture alternatives. This selection of kinesthetic activities was designed to stimulate all learning styles, but especially to provide the athletes, musicians, and artists in his classroom with some success and to foster a love for language and literature in all of his students.

The report titled, "Enhancing vocabulary and Language Using Multiple Intelligences" by Pat Condis, Diana parks and Rita Soldwedel describes a program for evolving language development through the use of multiple intelligences. An investigation on the profile of the learners showed that they neither at home nor at school were they offered a variety of learning strategies that could address multiple intelligences. The analysis of results showed a considerable improvement in students' language with a concentrated and regular intervention using the multiple intelligences.

A study by Fozia Naseem and Dr. Fauzia Naeem Khan titled, " Theory of Multiple Intelligences in Classroom: A Case study of Karachi" attempted to find out whether opportunities were provided to children in private public and community based schools to cater to multiple intelligences. Through interview based semi structured questionnaire and class observations, the paper attempted to gauge what strategies were employed in the classrooms to meet the various intelligences of children. It was observed that in the schools of all three sectors much importance was placed on verbal-linguistic and logical mathematical intelligences whereas strategies to trigger the other intelligences were not given emphasis. The assessment techniques in the public and private schools were also based on written examinations conducted at fixed period. However, the community based schools are observed to be better followers of MI theory in terms of assessments and curriculum development. The study recommends an in-depth understanding of the concept of $\mathrm{MI}$ through formal training given to the teachers. It further suggests that the community members, the state and parents should also be made a part of this process of change.

Mary E. Buschick, et al in an Action Research Project, May 2007, titled "Increasing Reading Motivation in Elementary and Middle School Students Through the Use of Multiple Intelligences." The objective of this project was to increase reading motivation 
in elementary and middle school students using of multiple intelligences. The study showed that the two most dominated intelligences in the classroom were verbal/linguistic and interpersonal, while the least dominated were intrapersonal and naturalistic intelligence. The teacher researchers decided to employ multiple intelligences as their principal solution to increasing reading motivation in elementary and middle school students. The teachers incorporated a number of activities to cater to multiple intelligences. The results of the student survey showed that there was an increase of students reading at home and their interest in reading. The teachers became more understanding of the requirements and needs that students had owing to their dominant intelligence through this study.

\section{Research Objectives}

The research aims to

- Identify the type of intelligence dominant in the target group

- Identify the teaching methods used to teach the target group

- $\quad$ Find out whether the teaching methods cater to the type of intelligence the target group has?

\section{Problem Statement}

This paper will find out what sort of intelligences the students of different Communication courses have and whether the teaching methods cater to these intelligences or not; and if they do to what extent each intelligence is catered to.

\section{Hypotheses}

The literature review of the researches conducted helped to formulate the following hypotheses:

1. The target group, i.e., students of Communication at the Institution in question, is diverse in terms of multiple intelligences

2. The teaching methodologies at the institution employ different ways to cater to the dominant intelligences of the target group.

As there is no acknowledged test particularly devised to find out the dominant intelligence in learners, no research paper in the literature review attempts to find out the dominant intelligences of the target group. The questionnaire used in this study has been formulated by the researcher on her own, with the help of the description of nine intelligences from the literature review. 


\section{Research Methodology This research was both quantitative and descriptive.}

\subsection{Target Group}

The target group of this study was the students of Communication at a business school in Karachi. Hundred students were a part of this study but only 96 questionnaires which were completely filled out were included in the study.

\subsection{Data Collection and Methodology. The sampling was convenience based.}

A questionnaire was formulated on the basis of literature review read for this research. Likert Scale was employed in the questionnaire. Questions of Part one of the questionnaire were formulated to find out which intelligences the target group had: question 1-5 were based on Visual-Spatial Intelligence; question 6-10 on Linguistic-Verbal Intelligence; 11-14 on Logical-Mathematical Intelligence; 15-18 on Bodily-Kinesthetic Intelligence; 19-22 on Musical Intelligence; 23-26 on Interpersonal Intelligence; 27-30 on Intrapersonal Intelligence; 31-34 on Naturalistic Intelligence; question 31 was based on Existential intelligence.

In the second part of the questionnaire the target group was asked about the class activities they were involved in. Question 1-4 were formulated to find out whether they were involved in activities/teaching methods that catered to Linguistic-Verbal Intelligence; question 5-11 asked them if they were involved in activities/teaching methods that catered to Visual-Spatial Intelligence; question 12-14 were formulated to find out whether Musical Intelligence was catered to; question 15-20, 21-23 , 24-26 and 27-28 were formulated to find out whether they were involved in activities/teaching methods that catered to Bodily-Kinesthetic Intelligence; Logical-Mathematical Intelligence; Interpersonal Intelligence and Intrapersonal Intelligence, respectively; question 29 was formulated to find out whether Naturalistic Intelligence was catered to and question 30 was formulated whether they were involved in activities/teaching methods that catered to existential intelligence.

\subsection{Data Analysis Methodology}

The response to each questions in the questionnaire was considered positive when out of $4 / 5$ questions, 3 were responded in the affirmative (i.e., always /mostly). All responses were then ranked in a sequence. Spearman Co relation Co efficient was used for data analysis.

\section{Results}

Spearman rank correlation coefficient '?' was 0.04 (statistically not different from zero). The class activities did not cater to students predominant "intelligence" as shown by the ranking in the two orders were different with the exception of one intelligence (Table $1-2)$. 


\begin{tabular}{lll}
\hline & \multicolumn{2}{c}{ Table 1. Rank order of the student intelligence } \\
\hline 1 & Bodily-Kinesthetic Intelligence & $88(92)$ \\
2 & Interpersonal Intelligence & $85(88)$ \\
3 & Intrapersonal Intelligence & $76(79)$ \\
4 & Naturalistic Intelligence & $73(76)$ \\
5 & Mathematical Intelligence & $72(75)$ \\
6 & Visual- spatial Intelligence & $70(73)$ \\
7 & Linguistic Intelligence & $69(72)$ \\
7 & Existential Intelligence & $69(72)$ \\
9 & Musical Intelligence & $56(58)$ \\
\hline
\end{tabular}

*number and percentage $\mathrm{n}(\%)$

Table 2. Rank order of the intelligences catered to in the class activities/teaching methodologies

\begin{tabular}{lll}
\hline 1 & Linguistic Intelligence & $76(79)$ \\
1 & Interpersonal Intelligence & $76(79)$ \\
3 & Visual- spatial Intelligence & $72(75)$ \\
4 & Naturalistic Intelligence & $62(65)$ \\
5 & Existential Intelligence & $56(58)$ \\
6 & Mathematical Intelligence & $55(57)$ \\
7 & Bodily-Kinesthetic Intelligence & $49(51)$ \\
8 & Musical Intelligence & $45(47)$ \\
9 & Intrapersonal Intelligence & $14(15)$ \\
\hline
\end{tabular}

${ }^{*}$ number and percentage $\mathrm{n}(\%)$

\section{Discussion}

The distribution of various intelligences in the study group was as follows: Bodily/Kinesthetic $88(92 \%)$, interpersonal $85(88 \%)$, intrapersonal intelligence $76(79 \%)$, naturalistic intelligence $73(76 \%)$, mathematical intelligence $72(75 \%)$, visual-spatial intelligence $70(73 \%)$, linguistic intelligence $69(72 \%)$, existential intelligence $69(72 \%)$ and musical intelligence $56(58 \%)$ as shown in Table 1 . The majority of the classroom activities catered to linguistic intelligence $76(79 \%), 76(79 \%)$ of class activities catered to interpersonal intelligence, $72(75 \%)$ catered to visual- spatial intelligence, $62(65 \%)$, $56(58 \%), 55(57 \%), 49(51 \%), 45(47 \%)$ and $14(15 \%)$ catered to naturalistic, existential, mathematical, bodily-kinesthetic intelligence, musical and intrapersonal intelligence, respectively (Table 2 ). Table 1 shows that body-kinesthetic intelligence $88(92 \%$ ) was 
predominant in the students followed by interpersonal $85(88 \%)$ and intrapersonal intelligence $76(79 \%)$. However, the class room activities catered predominantly to linguistic intelligence in 76(79\%) followed by interpersonal 76(79\%) and visuo-spatial intelligence in $72(75 \%)$, respectively (Table 2). Only the classroom activities catering to natural intelligence $62(65 \%)$ correlated with natural intelligence $73(76 \%)$ of the target group (Table 1-2).

The class activities did not cater to students' predominant "intelligence" as shown by the ranking in the two orders. The ranks were different, with the exception of naturalistic intelligence, which is the fourth in both rank orders. This means that a good emphasis is given to group work, solving communication problems at work and responding to requests, sales letters, etc. in the communication classroom in the university in question.

The most dominant intelligence in the target group is Bodily-Kinesthetic Intelligence but the results show that only few class activities cater to this intelligence. The third dominant intelligence in number was Intrapersonal Intelligence and once again in the rank of intelligences catered to in the class, this intelligence was the last one, which means that this type if intelligence is almost ignored in the class and the students in whom this intelligence dominates will only engage in other activities that do not cater to their needs.

The study shows that the majority of class activities were based on Linguistic Intelligence (which is on rank seven on the rank order of the dominant intelligences in the target group), such as, rewriting/revising messages, writing and reading assignments and oral presentations only and therefore will not cater to a classroom which is diverse in terms of multiple intelligences. Therefore, the first hypothesis, i.e., the target group, i.e., students of Communication at the Institution in question, is diverse in terms of multiple intelligences has been validated in the research whereas the second one, i.e., the teaching methodologies at the institution employ different ways to cater to the dominant intelligences of the target group has been rejected by the analysis of the results of the research.

\section{Conclusion}

This study shows that target group is diverse in terms of multiple intelligences but the ranking of target group intelligence do not correlate with that of class activities used to teach these students. The linguistic intelligence, predominantly catered to in the class activities, was not the dominant intelligence in this group and the dominant intelligence, i.e., Bodily-Kinesthetic is not catered to by the majority of the teaching activities. It is important to determine dominant intelligences in a class room and plan out activities/ teaching methodologies that match with the preferred learning styles to those intelligences so as to achieve the desired goals in the field of education.

\section{Limitations of the study}

The limitation of the study was that there were no authentic tests for multiple intelligences available or used in the studies discussed in the literature review that could have been 
used as a sample. Hence, the reliability and authenticity of the questionnaire used in this research can be questioned. 


\section{References}

Abdallah, Mahmoud (2008) Multiple ways to be smart: Gardener's Theory of Multiple Intelligences and its Educational Implications in English Teaching and Oral Communication Retrieved March, 1, 2009 Website: www.eric.ed.gov/ERICWebPortal

Armstrong, T. (1994) "Multiple intelligences: Seven ways to approach curriculum." Educational Leadership. 52(3). Retrieved, May, 12, 2001, from http://www.ascd.org/readingroom/edlead/9411/armstrong.html

Buschick, Mary E. (2007) Increasing Reading Motivation in Elementary And Middle School Students Through the Use of Multiple Intelligences Retrieved March, 1, 2009 from Website www.eric.ed.gov/ERICWebPortal

Cahill, S. M. (1999): "Shakespeare's multiple intelligences: Howard Gardner's theory of multiple intelligences as reflected in Shakespeare's plays." UMI Dissertations. Retrieved April, 12, 2001, from http://wwwlib.umi.com/dissertations/preview_all/9944399

Campbell, L. (1997): "Variations on a theme: How teachers interpret MI theory." Educational Leadership 55(1)

Condis, Pat, et al (2000) Enhancing vocabulary and Language Using Multiple Intelligences Retrieved January 20, 2009, from Website: www.eric.ed.gov/ERICWebPortal

Dorathy, S. (1999) "Multiple intelligences." Retrieved March, 23, 2009, http://dana.ucc.nau.edu/ shd/

El Naggar, Z. (2000) Learners' individual differences." In: El Naggar, Z.; Fadel, R.; Hanaa, R.; McCloskey, M. \& Thornton, B. (Eds): SPEER (Spotlight on Primary English Education Resources): A resource text for Egyptian primary English educators, supervisors and teachers. Academy for Educational Development.

Gardner, H. (1993): Frames of mind: The theory of multiple intelligences. (10th anniversary Ed). BasicBooks.

Gardner, H. (1999): Intelligence reframed: Multiple intelligences for the 21st century. New York, BasicBooks.

Goodnough, K. (2000): "Exploring Multiple Intelligences Theory in the Context of Science Education: An Action Research Approach." UMI Dissertations. Retrieved April, 25, 2001, from http://wwwlib.umi.com/dissertations/preview_all/NQ4985

McKenzie, Walter It's Not How Smart You Are, It's How You Are Smart! Retrieved March, 23, 2009, from Website http://surfaquarium.com/Mi/overview.htm Multiple Intelligences Retrieved March, 23, 2009, from Website http://www.thomasarmstrong.com/multiple_intelligences.htm 
Naeem, Dr. Fauzia and Nasim, Fozia [2008] Theory of Multiple Intelligences in Classroom: A Case Study of Karachi, Journal of Independent Studies and Research( JSIR), vol. 6, no. 2, Retrieved January 3, 2009, from Website: http://zabdesk.szabist.edu.pk/

Safi, Anna Marie (1996)Ditch the Dictionary: Finding a Comfortable Vocabulary Zone Retrieved January 20, 2009, from Website: www.eric.ed.gov/ERICWebPortal

Schallar, Kristie A \& Callison Marybeth.G (1996) Multiple Intelligence and Student Learning: Reframing our Teaching Methods in the Basic Public Speaking Course" Retrieved February 20, 2009, from Website: www.eric.ed.gov/ERICWebPortal

Peter Smagorinsky (1995) Multiple Intelligences in the English Class: An Overview Retrieved February 23, 2009, from Website: www.jstor.org

Wendy F. Simeone (1995) the paper, "Accommodating Multiple Intelligences in the English Classroom" Retrieved February 25, 2009, from Website: www.eric.ed.gov/ERICWebPortal

White, N.; Blythe, T. \& Gardner, H. (1995): "Multiple Intelligences Theory: Creating the Thoughtful Classroom." In: Fogarty, R.; Bellanca, J.; Hauker, M., (Eds). Multiple intelligences: A collection. Hauker, Brownlow Education. 


\section{Appendix}

\section{Questionnaire}

This questionnaire will be used for a research project. The information collected will be kept confidential.

Name (optional):

Gender:

Age:

Note: Please tick the appropriate answer.

\begin{tabular}{|c|c|c|c|c|}
\hline 1 & Do you enjoy reading and writing? & $\begin{array}{l}\text { Always } \\
\text { Never }\end{array}$ & Mostly & Occasionally \\
\hline 2 & Are you good at putting puzzles together? & $\begin{array}{l}\text { Always } \\
\text { Never }\end{array}$ & Mostly & Occasionally \\
\hline 3 & $\begin{array}{l}\text { Are you good at interpreting pictures, } \\
\text { graphs and charts? }\end{array}$ & $\begin{array}{l}\text { Always } \\
\text { Never }\end{array}$ & Mostly & Occasionally \\
\hline 4 & $\begin{array}{l}\text { Do you enjoys drawing, painting } \\
\text { and the visual arts? }\end{array}$ & $\begin{array}{l}\text { Always } \\
\text { Never }\end{array}$ & Mostly & Occasionally \\
\hline 5 & Do you recognize patterns easily? & $\begin{array}{l}\text { Always } \\
\text { Never }\end{array}$ & Mostly & Occasionally \\
\hline 6 & $\begin{array}{l}\text { Are you good at remembering written } \\
\text { and spoken information? }\end{array}$ & $\begin{array}{l}\text { Always } \\
\text { Never }\end{array}$ & Mostly & Occasionally \\
\hline 7 & Do you enjoy reading and writing? & $\begin{array}{l}\text { Always } \\
\text { Never }\end{array}$ & Mostly & Occasionally \\
\hline 8 & $\begin{array}{l}\text { Are you good at debating or } \\
\text { giving persuasive speeches? }\end{array}$ & $\begin{array}{l}\text { Always } \\
\text { Never }\end{array}$ & Mostly & Occasionally \\
\hline 9 & Are you able to explain things well? & $\begin{array}{l}\text { Always } \\
\text { Never }\end{array}$ & Mostly & Occasionally \\
\hline 10 & $\begin{array}{l}\text { Do you often use humor when } \\
\text { telling stories? }\end{array}$ & $\begin{array}{l}\text { Always } \\
\text { Never }\end{array}$ & Mostly & Occasionally \\
\hline 11 & $\begin{array}{l}\text { Are you good at problem-solving skills? } \\
\text { Never }\end{array}$ & Always & Mostly & Occasionally \\
\hline 12 & $\begin{array}{l}\text { Do you enjoy thinking about abstract } \\
\text { ideas? }\end{array}$ & $\begin{array}{l}\text { Always } \\
\text { Never }\end{array}$ & Mostly & Occasionally \\
\hline 13 & $\begin{array}{l}\text { Do you like conducting scientific } \\
\text { experiments? }\end{array}$ & $\begin{array}{l}\text { Always } \\
\text { Never }\end{array}$ & Mostly & Occasionally \\
\hline 14 & $\begin{array}{l}\text { Are you good at solving complex } \\
\text { computations? }\end{array}$ & $\begin{array}{l}\text { Always } \\
\text { Never }\end{array}$ & Mostly & Oc \\
\hline
\end{tabular}


15 Are you good at dancing and sports?

\begin{tabular}{|c|c|c|}
\hline $\begin{array}{l}\text { Always } \\
\text { Never }\end{array}$ & Mostly & Occasionally \\
\hline $\begin{array}{l}\text { Always } \\
\text { Never }\end{array}$ & Mostly & Occasionall \\
\hline $\begin{array}{l}\text { Always } \\
\text { Never }\end{array}$ & Mostly & Occasionall \\
\hline $\begin{array}{l}\text { Always } \\
\text { Never }\end{array}$ & Mostly & Occasionally \\
\hline $\begin{array}{l}\text { Always } \\
\text { Never }\end{array}$ & Mostly & Occasionall \\
\hline $\begin{array}{l}\text { Always } \\
\text { Never }\end{array}$ & Mostly & Occasionally \\
\hline $\begin{array}{l}\text { Always } \\
\text { Never }\end{array}$ & Mostly & Occasionall \\
\hline $\begin{array}{l}\text { Always } \\
\text { Never }\end{array}$ & Mostly & Occasionally \\
\hline Always & Mostly & Occasionall \\
\hline $\begin{array}{c}\text { Always } \\
\text { Never }\end{array}$ & Mostly & Occasionally \\
\hline $\begin{array}{l}\text { Always } \\
\text { Never }\end{array}$ & Mostly & Occasionall \\
\hline $\begin{array}{l}\text { Always } \\
\text { Never }\end{array}$ & Mostly & Occasionall \\
\hline $\begin{array}{l}\text { Always } \\
\text { Never }\end{array}$ & Mostly & Occasionally \\
\hline $\begin{array}{l}\text { Always } \\
\text { Never }\end{array}$ & Mostly & Oc \\
\hline $\begin{array}{l}\text { Always } \\
\text { Never }\end{array}$ & Mostly & Occasionally \\
\hline $\begin{array}{l}\text { Always } \\
\text { Never }\end{array}$ & Mostly & ionall \\
\hline $\begin{array}{l}\text { Always } \\
\text { Never }\end{array}$ & Mostly & Occasionall \\
\hline $\begin{array}{l}\text { Always } \\
\text { Never }\end{array}$ & Mostly & Occasionall \\
\hline $\begin{array}{l}\text { Always } \\
\text { Never }\end{array}$ & Mostly & Occ \\
\hline
\end{tabular}

33 Do you enjoy camping, gardening, hiking and exploring the outdoors? 
34 Do you enjoy learning topics have connection to nature?

Always Mostly Occasionally
Never

35 Are you sensitive to, or have the capacity for, conceptualizing or tackling deeper or larger questions about human existence, such as the meaning of life, why are we born, why do we die, what is consciousness, or how did we get here? Always Mostly Occasionally Never

In this part of the questionnaire you will have to tick the class activities your are involved in

\begin{tabular}{|c|c|c|c|c|}
\hline 1 & $\begin{array}{l}\text { Rewriting/revising } \\
\text { messages/ speeches }\end{array}$ & $\begin{array}{c}\text { Always } \\
\text { Never }\end{array}$ & Mostly & Occasionally \\
\hline 2 & Writing assignments & $\begin{array}{l}\text { Always } \\
\text { Never }\end{array}$ & Mostly & Occasionally \\
\hline 3 & Reading assignments & $\begin{array}{l}\text { Always } \\
\text { Never }\end{array}$ & Mostly & Occasionally \\
\hline 4 & Debating or giving persuasive speeches & $\begin{array}{l}\text { Always } \\
\text { Never }\end{array}$ & Mostly & Occasionally \\
\hline 5 & Reading & $\begin{array}{l}\text { Always } \\
\text { Never }\end{array}$ & Mostly & Occasionally \\
\hline 6 & Writing & $\begin{array}{l}\text { Always } \\
\text { Never }\end{array}$ & Mostly & Occasionally \\
\hline 7 & Interpreting a message & $\begin{array}{l}\text { Always } \\
\text { Never }\end{array}$ & Mostly & Occasionally \\
\hline 8 & Videos & $\begin{array}{l}\text { Always } \\
\text { Never }\end{array}$ & Mostly & Occasionally \\
\hline 9 & Pictures & $\begin{array}{l}\text { Always } \\
\text { Never }\end{array}$ & Mostly & Occasionally \\
\hline 10 & Charts & $\begin{array}{c}\text { Always } \\
\text { Never }\end{array}$ & Mostly & Occasionally \\
\hline 11 & Explaining things & $\begin{array}{l}\text { Always } \\
\text { Never }\end{array}$ & Mostly & Occasionally \\
\hline 12 & $\begin{array}{l}\text { Music/rhythm incorporated into } \\
\text { report/oral presentations }\end{array}$ & $\begin{array}{l}\text { Always } \\
\text { Never }\end{array}$ & Mostly & Occasionally \\
\hline 13 & Write about the importance of music & $\begin{array}{l}\text { Always } \\
\text { Never }\end{array}$ & Mostly & Occasionally \\
\hline 14 & $\begin{array}{l}\text { Use of music in the background } \\
\text { while writing messages }\end{array}$ & $\begin{array}{l}\text { Always } \\
\text { Never }\end{array}$ & Mostly & Occasionally \\
\hline 15 & $\begin{array}{l}\text { Speeches/ writings about the importance } \\
\text { of sports/wellness programs at work }\end{array}$ & $\begin{array}{l}\text { Always } \\
\text { Never }\end{array}$ & Mostly & Occasionally \\
\hline
\end{tabular}


16 Transferring new information from the text books to a other medium, such as

Always

Mostly Occasionally

computers and posters

17 Role plays

Always

Mostly Occasionally

Never

18 Projects

Always Mostly Occasionally

Never

19 Games

Always

Never

Mostly Occasionally

20 Describe objects related to the subject by touching or operating

Always

Mostly Occasionally

Never

21 Exercises dealing with problem solving, such as, what sort of messages would

Always Never be appropriate in the given situation

22 Puzzles/ crosswords

Always

Mostly Occasionally

Never

23 Matching exercises

Always

Mostly Occasionally

Never

$24 \quad$ Group work

Always

Never

Mostly Occasionally

Always

Never

Mostly Occasionally problems at work

26 Responding to requests, sales letters, etc

Always

Never

27 Report writing/ letters presentations about your self (self disclosure/ self awareness/ your goals)

28 Keep a journal about your speaking/ writing experience

Always

Never

Mostly Occasionally

Mostly Occasionally

Always Mostly Occasionally

Never

Always Mostly Occasionally

29 Observe communication between individuals at real workplace

Never

Always Mostly Occasionally

30 Questions about human existence, such as the meaning of life, why are we born, why do we die, what is Never consciousness, or how did we get here. 